\title{
Choice Of Exchange Rate Regimes For Developing Countries: Better Be Fixed Or Floating?
}

Elif O. Kan, (E-mail: elifoznurkan@cankaya.edu.tr), Cankaya University, Turkey

\begin{abstract}
The following paper is a summary article about the choice of exchange rate regime for a developing country considering the importance of "currency mismatches", "debt intolerance", "and fear of floating", "financial globalization", "institutions and sudden stops". In this paper, I first summarize recent researches and papers on this specific issue. In a recent work of theirs, Calvo and Mishkin(2003) argue that much of the debate on choosing an exchange rate regime misses the boat and concludes that choice of exchange rate regime is likely to be of second order importance to the development of good fiscal, financial, and monetary institutions in producing macroeconomic success in emerging market countries and that a focus on institutional reforms rather than on the exchange rate regime may encourage emerging market countries to be healthier and less prone to the crises that we have seen in recent years. Another major study in this subject belong to Obtsfeld(2004) which claim that the measurable gains from financial integration appear to be lower for emerging markets than for higher-income countries, and appear to have been limited by recent crises. Obtsfeld identifies one factor limiting the gains from financial integration as the difficulty emerging economies face in resolving the open-economy trilemma which claim that many emerging economies cannot live comfortably either with fixed or with freely floating exchange rates. And finally, Stanley Fisher (2001) discusses the bipolar or two-corner solution view of intermediate policy regimes between hard pegs and floating are not sustainable and that use of pegged rates for countries open to international capital flows. Finally, I sum up with some concluding remarks.
\end{abstract}

\section{INTRODUCTION}

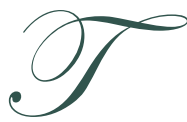

he choice of exchange rate regime has been a subject of ongoing debate in international economics. This debate has been renewed in recent years because of two main factors. First, unsustainable exchange rate regimes were widely perceived to have been one of the causes in a series of economic crises, including the Exchange Rate Mechanism (ERM) crisis in 1992, the Mexican peso crisis in 1994-95, and the Asian crisis in 1997-98. This has led some economists to suggest that, in a world of increasing international capital mobility, only the two extreme exchange rate regimes are likely to be sustainable; either a permanently fixed exchange rate regime (i.e.hard peg) such as a currency board or monetary union, or a freely floating exchange rate regime. This proposition, known as the hollowing-out hypothesis, or the bipolar view, is gaining popularity. It is not, however, universally accepted. Indeed, some economists believe that intermediate regimes such as the adjustable pegged exchange rate will continue to be a viable option, especially for emerging markets. Second, certain experiments with new arrangements over the past decade, such as the European Economic and Monetary Union (EMU), dollarization in Ecuador and El Salvador, and currency boards in Hong Kong and Estonia, have reinforced the view that hard fixes may be the best exchange rate arrangement for some countries. 
Although the choice of exchange rate regime is a topic of interest for all countries, it is considered particularly relevant for emerging markets, because other countries are perceived either as having no alternative to their current exchange rate arrangement or as highly unlikely to make a significant change. The former group, those with no viable alternative, includes countries that are either too small or too underdeveloped to entertain other options; the latter, those who are unlikely to change, are mainly industrialized countries that have tended to settle at one of the two extremes; either opting for a freely floating currency or moving to a common currency such as the euro.

Emerging markets are also regarded as an interesting group by those who hold the bipolar view because these markets are in the process of integrating into global capital markets and are thus viewed as potentially being drawn towards one of the two poles. The choice of exchange rate regime for emerging markets is thus receiving more attention, both in the literature and in policy circles.

In this article, the evolution of exchange rate regimes and its relationship with the institutions in emerging markets over the past decade are reviewed, discussing the factors that determine how such countries make their choices and examining the available options.

\section{EVOLUTION Of EXCHANGE RATE REGIMES IN EMERGING ECONOMIES}

Proponents of the bipolar view, including Obstfeld and Rogoff (1995) and Eichengreen (1998), predict that countries that have integrated, or are integrating, their domestic capital markets with global capital markets will be unable to sustain intermediate regimes and will be forced to choose one of the two extremes: either a hard fix or a freely floating exchange rate regime. In their opinion, the middle ground - made up of adjustable (soft) pegs — will eventually vanish for countries that are open to international capital flows. Other authors, however, disagree. Williamson (2000), for example, believes that intermediate regimes are, and will continue to be, a viable option for emerging markets. Masson (2001) has tested the bipolar hypothesis directly, using historical data, and finds that intermediate regimes are no more likely to disappear than freely floating or firmly fixed exchange rate systems. This section reviews the evidence supporting the bipolar hypothesis, looking at the evolution of exchange rate regimes in emerging markets over the past decade.

Fischer (2001) documented the case for the bipolar view by examining the evolution of exchange rate regimes in a large sample of countries over the 1990s. His evidence identifies a trend away from intermediate regimes and towards floating regimes, but does not go so far as to suggest that the middle is vanishing, except for industrialized countries. 1 Of the 185 countries in the sample, one-third had intermediate regimes in 1999, down from nearly two-thirds (62\%) in 1991. Yet despite this substantial decrease in the number of countries with intermediate regimes throughout the 1990s, there is currently no evidence to suggest that they are about to disappear. Hard fixes also became more popular throughout the 1990s, largely due to the creation of the EMU. Notwithstanding this unique event, hard fixes only increased from 16 per cent to 24 per cent of total regimes over the 1990s. In emerging market countries, intermediate regimes declined from 64 per cent to 42 per cent, whereas floating regimes increased from 30 per cent to 48 per cent; the remaining 10 per cent were hard fixes. Thus, in 1999, there were almost as many intermediate regimes as there were floating regimes in emerging markets.

Calvo and Reinhart (2002), using more traditional economic analysis and taking into account movements in commodity prices, arrive at a similar conclusion. They focus on countries that officially claim to be on a floating exchange rate regime, and find that, in most cases, these countries have not allowed their exchange rate to float freely. They interpret their findings as evidence of "fear of floating."

In summary, although the evidence to date shows that the popularity of intermediate regimes declined in the 1990 s, it is unclear at this point whether they are in the process of becoming extinct. The strongest evidence for the bipolar view comes from the industrialized countries, where most have adopted exchange rate regimes at one of the two extremes. For emerging markets, however, intermediate regimes remain a popular choice. 
After summarizing the main literature briefly, the later sections of the paper aims to address the researches and concerns regarding the choice of exchange rate regime for a developing country, by summarizing the pioneer studies of famous scholars and researchers such as Calvo and Mishkin, Fisher and Obtsfeld. Now let us pinpoint one by one what they say.

\section{INSTITUTIONAL REFORMS ARE SUPERIOR TO CHOICE OF EXCHANGE RATE REGIMES IN PRODUCING MACOECONOMIC SUCCESS FOR DEVELOPING COUNTRIES}

According to a recent paper, by Guillermo Calvo, of the Inter-American Development Bank, and Frederic Mishkin, of Columbia University, the choice of monetary regime matters less than the creation of good monetary, fiscal and financial institutions. Calvo and Mishkin argue that when governments run up huge debts, banks are poorly supervised and the central bank prints money recklessly, people can have no faith in the real value of money. Governments might therefore fix the exchange rate in the hope that a tie to a strong currency will give them credibility and build confidence in the value of the national money. Then again, they might follow the advice of those who favour floating exchange rates, because then monetary policy should have the flexibility to deal with domestic economic concerns. However, none of this means much without good institutions. Like governments, monetary-policy regimes are rarely ideal, and the best system may vary from one country to the next. But Calvo and Mishkin claim that governments should worry first about setting up institutions on which their citizens and investors can rely, and only then ponder the finer points of which variables should be the target of their central-banks. Below, the paper is summarized in depth.

Calvo and Mishkin (2003) discuss the standard theory of choice between exchange rate regimes, along with its weaknesses which arise when applied to emerging market economies. They try to establish a relationship between a range of institutional traits of a country and choice of its exchange rate regimes. They interrogate if there is causality between the development of successful fiscal, financial and monetary institutions and the countryspecific fact that whether a floating or fixed exchange rate is preferred. As in the many other papers considering this issue, Calvo and Mishkin also start with pointing out the devastating financial crises and macroeconomic turbulence which were experienced by a number of emerging countries including Argentina(2001-2002), Turkey(2000-2001), Ecuador(1999), Russia(1998), East Asia(1997), Mexico(1994-1995 and Chile(1982). Based on these crises, the authors try to find out how the choice of exchange rate regime might have contributed to macroeconomic instability and conversely, how a shift in exchange rate regime might contribute to improved macroeconomic performance by addressing the following specific question:

Should an emerging market economy prefer a floating exchange rate, a fixed exchange rate, or some blend of the two like an exchange rate that was usually fixed but might sometimes shift? (Calvo and Mishkin, 2003)

The most notable crises of East Asia has proved that nations must make a bipolar choice: either choose a framework for credibly guaranteeing a fixed exchange rate, known as a hard peg by utilising either currency board or full dollarization or else accept a freely floating exchange rate. On the other hand, neither of these extreme exchange rate regimes has a successful record. For example, Argentina chose the currency board approach for ensuring a fixed exchange rate. From a legal perspective, the central bank of Argentina was highly independent. But in 2001, large budget deficits, burden of state owned banks forced the Argentine government to look for a new source of funds. So banks were encouraged and coerced into purchasing Argentine government bonds to fund the fiscal debt. An attempt was made to reactivate the economy via expansive monetary policy. The likely insolvency of the banks then led to a banking crisis by the end of 2001. Because most debt instruments in Argentina were denominated in U.S. dollars, the depreciation of the Argentinean currency made it impossible for borrowers to earn enough Argentinean currency to repay their dollar-denominated loans. The Argentine financial sector melted down, and the economy as well. Argentina's experiment with its currency board ended up in disaster.

The remaining option of freely floating exchange rates seems unattractive as well. But in many emerging market economies, exports, imports, and international capital flows are a relatively large share of the economy, so large swings in the exchange rate cause very substantial swings in the real economy. Even a central bank that would prefer to let the exchange rate float must be aware that, if the country's banks have made loans in U.S. dollars, then 
a depreciation of the currency vs. the dollar can greatly injure the financial system. Under these circumstances, the monetary authority is likely to display "fear of floating"(Calvo and Reinhart, 2002), defined as a reluctance to allow totally free fluctuations in the nominal or real exchange rate. Thus, the literature on exchange rate regimes seems to have backed itself into a corner where none of the available options is without problems.

The Standard Theory of Choosing an Exchange Rate Regime is mainly based on the theory of optimal currency areas of Mundell (1961) and Poole (1970). These models of choosing an exchange rate regime typically evaluate such regimes by how effective they are in reducing the variance of domestic output in an economy with sticky prices as stated below:

If an economy faces primarily nominal shocks - that is, shocks that arise from money supply or demand - then a regime of fixed exchange rates looks attractive. If a monetary shock causes inflation, it will also tend to depreciate a floating exchange rate and thus transmit a nominal shock into a real one. In this setting, the fixed exchange rate provides a mechanism to accommodate a change in the money demand or supply with less output volatility. On the other hand, if the shocks are real - like a shock to productivity, or to the terms of trade (that is, the relationship between export prices and import prices shifts due to movements in demand or supply) - then exchange rate flexibility of some sort becomes appealing. In this case, the economy needs to respond to a change in relative equilibrium prices, like the relative price of tradable with respect to nontradables. A shift in the nominal exchange rate offers speedy way of implementing such a change - thus, ameliorating the impact of these shocks on output and employment. (Calvo and Mishkin, 2003)

The theory however fails when applied in emerging economies. This is called as The Mundell Challenge which states that the optimality of fixed exchange rates within a given country for different regions cannot be taken for granted as opposed to what the standard theory indicates. The responsive arguments to Mundell Challenge are that internal mechanisms such as labour mobility between regions, compensatory fiscal transfers can substitute for regional exchange rate variability. However, these arguments are not found not to be persuasive as well.

Considering the emerging market economies, the standard theory has a number of inapplicable implicit assumptions that do not hold. The ability to set up institutions that will assure a fixed exchange rate, a timeconsistent choice on the exchange rate regime, focus on adjustments in goods and labour markets and the financial sector and no attention paid to transaction costs and liquidity considerations are some of these key assumptions of the standard theory which do not always hold in developing economies. Calvo and Mishkin then identify several institutional features that are common in emerging market economies: weak fiscal, financial, and monetary institutions; currency substitution and liability dollarization: and vulnerability to sudden stops of outside capital flows.

The first feature that is common across emerging economies is weak fiscal, financial and monetary institutions which increase vulnerability to high inflation and currency crises. In these economies, fiscal policy puts pressure on the monetary authorities to monetize the debt. This produces rapid money growth along with high inflation and depreciation of the domestic currency. Similarly, poor regulation and supervision of the financial system can result in large losses in bank balance sheets that make it impossible for the monetary authorities to raise interest rates to control inflation because doing so may lead to a collapse of the financial system. Weak monetary institutions indicate that the monetary authorities cannot keep inflation under control or prevent large depreciations of the currency. To sum, in such an economy where the government has large fiscal deficits, banks are poorly regulated, and the central bank may continuously expand the money supply, the real value of money cannot be taken for granted. In such a case, firms and individuals in emerging market countries react to the threat that the value of their money may change in value through inflation or the exchange rate by making currency substitution. They then use foreign currency in a number of their transactions. This may increase even further to a level what we call as the liability dollarization where loans are all denominated in foreign currencies. In emerging market countries where there is liability dollarization, currency depreciation may cause borrowers to default on their payments and many bankruptcies. However, not all emerging market countries suffer from liability dollarization in a serious way. The most cited exceptions are Chile and South Africa, which have stronger monetary, fiscal and financial institutions. Another contributor to currency and financial crises is sudden stops which is confined to emerging market countries 
that experience large currency devaluations and have weak fiscal and financial institutions as given in the following table of Calvo and Mishkin (2003):

Table 1

The Incidence of Sudden Stops (SS), 1992-2001

\begin{tabular}{|c|c|c|}
\hline Event Type & $\begin{array}{c}\text { Emerging } \\
\text { Markets }\end{array}$ & $\begin{array}{l}\text { Developed } \\
\text { Economies }\end{array}$ \\
\hline Devaluations associated with SS & 12 & 4 \\
\hline Of which: First SS, then devaluation & 8 & 2 \\
\hline First devaluation, then SS & 4 & 2 \\
\hline Devaluations not associated with SS & 7 & 19 \\
\hline \multicolumn{3}{|l|}{ 2. aftatal } \\
\hline Event Type & $\begin{array}{l}\text { Emerging } \\
\text { Markets }\end{array}$ & $\begin{array}{l}\text { Developed } \\
\text { Economies }\end{array}$ \\
\hline Devaluations associated with SS & 63 & 17 \\
\hline Of which: First SS, then devaluation & 42 & 9 \\
\hline First devaluation, then SS & 21 & 9 \\
\hline Devaluations_not.associated with_SS & 37 & 83 \\
\hline
\end{tabular}

Note: A sudden stop is defined as a reversal in capital inflows that i) exceeds the mean minus two standard deviations of the annual change in capital inflows observed since 1990, and ii) is associated with a decline in output. The exercise also considers rises in the real exchange rate that i) exceed the mean plus two standard deviations of the annual change in the real exchange rate observed since 1990 , and ii) are greater than 20 percent. The sample consists of 15 emerging economies and 17 developed countries. See Calvo, Izquierdo and Mejia (2003) for further details and some sensitivity analysis.

Financial markets, which are underdeveloped in many emerging economies, are vulnerable to wild exchange-rate fluctuations. Large capital inflows that put upward pressure on real exchange rates are usually accompanied by too much borrowing and investment, and steep increases in asset prices. If investors lose confidence, these flows can go suddenly into reverse and the exchange rate falls. This means trouble: because investors are unwilling to lend in emerging-market currencies, local banks and companies end up laden with debts denominated in dollars and euros, while their assets are in the cheapened national currency. Defaults follow, and economic recovery can be slow. In countries where sudden stops are common, a floating exchange rate is a wrong choice since that it allows the sharp depreciation that worsens balance sheets and the financial sector. But under the weak institutions and sudden stops, it is not clear that a fixed exchange rate is sustainable, either. The authors argue that rather than focusing on the choice of exchange rate regime, an improvement in fiscal, financial, and monetary institutions will yield better results which would also limit the amount of currency substitution and liability dollarization, and also make the economy more resilient in reacting to sudden stops when they occur.

Calvo and Mishkin argue that choosing between exchange regimes is of second importance to economic institutions and characteristics of an economy for a emerging country to make economic success. However, they consider arguments in favour of both fixed and floating exchange rates for specific traits that are inherent in an economy. The first one is the ability to have domestic monetary policy which favours floating exchange rate regime since that it helps to maintain the flexibility to use monetary policy to focus on domestic considerations as stated below: 
One difficulty that emerging market economies face is that their capital markets are geared to interest rates set in major financial centres... In addition, emerging market economies may be hit as a group with financial contagion, as noted earlier, which will affect their interest rates. The central bank in an emerging market country thus faces real practical difficulties.

Building credible monetary institutions is a difficult task. It requires public and institutional commitment to price stability. The contrast between Argentina and Canada is instructive here. Legally, the central bank of Canada does not look particularly independent. In the event of a disagreement between the Bank of Canada and the government, the minister of finance can issue a directive that the bank must follow. However because the directive must be specific and in writing, and because the Bank of Canada is a trusted public institution, a government override of the bank is likely to cost the ruling party heavily in the polls. Thus, in practice the Bank of Canada is highly independent. In contrast, the central bank of Argentina was highly independent from a legal perspective. However, this did not stop the Argentine government from forcing the resignation of the highly respected president of the central bank and replacing him with a president who would do the government's bidding. It is unimaginable in countries like Canada, the United States or in Europe that the public would tolerate the removal of the head of the central bank in such a manner, and indeed we do not know of any case of this happening in recent history. (Calvo and Fisher, 2003)

On the other hand, the main weakness of a floating exchange rate is that it allows too much discretion to monetary policy and so may not provide a sufficient nominal anchor as stated below:

Of course, many emerging market countries have been able to keep inflation under control with flexible exchange rate regimes and this is why the evidence on whether fixed versus floating exchange rate regimes are associated with lower inflation rates on average is not clear cut. But a central bank can only work to reduce inflation if it is supported by the public and the political process. In some countries, giving the central bank an explicit focus on inflation targeting can help focus the public debate so that it supports a monetary policy focus on long-run goals such as price stability (Bernanke et al., 1999). However, these benefits require excellent communication skills on the part of the central bank in what can be a swirling political environment in emerging market countries. (Calvo and Mishkin 2003)

A danger of a hard exchange rate peg involves a risk of getting in a misaligned exchange rate:

Even in a country with a fixed nominal exchange rate, it is possible to use taxes and subsidies on imports and exports to alter the effective real exchange rate. For example, a uniform tax on imports accompanied by a uniform subsidy on exports of the same size is equivalent to a real currency depreciation - even though the nominal exchange rate stays unchanged. Moreover, a tax-and-subsidy-induced fiscal devaluation has one built-in advantage over nominal denomination. The fiscal devaluation has an upper bound, determined by the fact that beyond a certain point tax evasion becomes rampant. Nominal devaluation, on the other hand, has no upper bound and can lead to high inflation. (Calvo and Mishkin, 2003)

Advocates of hard exchange rate pegs on the other hand argue that it will promote openness to trade and economic integration and it can reduce the currency risk component in domestic interest rates and the borrowing costs for both government and private and financial sector, it is more sustainable if there is a liability dollarization in the country. On the other hand the main disadvantages of a hard peg exchange rate regime are that it may require large international reserves which provide collateral for public bonds and national debt, it cannot accommodate a money-printing lender of last resort.

Following the discussion on what institutional traits or policies affect the choice of a country's fixed or floating exchange rate above, the Calvo and Mishkin (2003) seek for a reverse causality of the choice of exchange rate regimes to cause different institutional and macroeconomic outcomes. There are again arguments in favour of both the fixed and the floating exchange rate regimes. Starting with the hard exchange rate supporters, they claim that this regime is a tool for improving fiscal institutions and budgetary management, since that if the central bank is 
focused on a fixed exchange rate, then the government no longer has access to the money printing press to finance its spending. Calvo and Mishkin refute this argument with the Argentina and Panama cases as below:

As the recent example of Argentina suggests, where the fiscal tensions between the provinces and the central government were not solved by the currency board, hard pegs may be less effective at constraining fiscal policy than was previously believed. Hard pegs may even weaken incentives for governments to put their fiscal house in order, because the hard peg may make it easier for governments to borrow foreign funds, thus allowing them to delay necessary reforms to fix fiscal imbalances. For example, Panama (which has been dollarized for close to a hundred years) has had poor fiscal performance, with fiscal deficits over 7 percent in the 1970s and averaging 5 percent in the 1980s - it is just in recent years that the fiscal position has improved to the point that the fiscal surplus averaged 1.4 percent during the 1990s. (Calvo and Mishkin, 2003)

Although it is not clear cut that floating regimes promotes fiscal responsibility, if inflation targeting is applied in a country government transparency and hence fiscal responsibility are clearly promoted. Calvo and Mishkin object also to another idea that favour hard exchange peg regimes that they promote healthier financial systems by avoiding currency mismatches and crises. They again use Argentina case for this objection as below:

A hard exchange rate peg in the form of a currency board might encourage unhedged dollar (foreigndenominated) liabilities that non-financial and financial firms might be willing to undertake, thus making the financial system more vulnerable in case the system has to be abandoned, as illustrated by Argentina in 2002. The hard peg might also encourage the issuance of dollar liabilities because financial firms would believe that the government would feel responsible for any devaluation and would, thus, be more likely to offer a bail-out. (Calvo and Mishkin, 2003)

The only relationship between hard exchange rate pegs and institutional traits that has some evidence is that they encourage openness to trade and integration with the countries to which the currency is pegged.

\section{THE OPEN ECONOMY-TRILEMMA and ITS EFFECTS ON EMERGING MARKETS' FINANCIAL INTEGRATION}

The policy dilemma that economies with fixed, or strongly pegged, rates of exchange, when opened to unrestricted capital flows loose the ability to use domestic monetary policy to alleviate declines in output and employment is called the "open economy trilemma", i.e. the choices forced upon the economy when the flexibility of one basic price, such as the rate of exchange, is lost. Quoting Obstfeld, 1998, pp. 14-15:

A country cannot simultaneously maintain fixed exchange rates and an open capital market while pursuing monetary policy oriented toward domestic goals. Governments may choose only two of the above. If monetary policy is geared toward domestic considerations, either capital mobility or the exchange rate must go. If fixed exchange rates and integration into the global capital market are the primary desiderata, monetary policy must be subjugated to those ends. (Obtsfeld, 1998)

Obtsfeld argues that open economy trilemma is an important factor that limits the gains from financial integration for emerging markets as quoted below:

In those countries, institutional distortions and market failures complicate credible inflation targeting, render large exchange rate movements more dangerous, make fixed exchange rates acutely crisis-prone, and apparently reduce the beneficial effects of financial liberalization. (Obtsfeld, 2004)

He classifies countries as high income, emerging and insular. The insular group which mainly consist of African countries are characterized by financially closed economies. Latin America and East Asia make up the middle-income emerging markets group. The financial criterion on which this classification is based is a sufficient degree of openness to private capital movements, or inclusion in the MSCI index. The effect of financial integration for emerging countries was to face the open economy trilemma as quoted below: 
During the 1950s and early 1960s, even small countries with fixed exchange rates maintained a modest degree of autonomy over monetary policy, thanks to imperfections in international capital mobility. As such mobility improved dramatically during the late 1960s and early 1970s, small developing countries (and not-so-small ones, like Mexico) were faced with choices new to them but familiar to small industrialized economies: letting their remaining monetary autonomy evaporate, imposing or tightening exchange controls, or abandoning fixed rates. (Alejandro, 1975)

The trilemma resulted in smaller net gains for non-industrial countries than it did in industrial countries. As did Calvo and Mishkin, Obtsfeld also points out to the importance of strong institutions for countries to both liberalize and practice complementary policy reforms, and thus experience positive economic outcomes with financial integration. This argument is quoted below:

For example, without effective prudential supervision of financial institutions, economic growth is likely to falter and capital inflows will likely aggravate the problems. A good institutional infrastructure, one in which the rule of law protects investor property rights, generates both good overall economic performance and an ability to reap net benefits from opening up to foreign capital. This linkage could help explain why poorer countries, which typically have weaker institutions, seem to gain less when they do open themselves to financial flows. (Obtsfeld, 2004)

According to Obtsfeld, better governments both liberalize external payments and create environments favourable to economic growth, but any independent effect of liberalization on growth remains unidentified in much of the linear cross-sectional analysis of growth effects. There could, however, be an important nonlinear interaction between quality of governance (which improves the prospects for productivity growth, raises returns to investment, and hence the demand for capital) and the benefits of financial opening (which speeds convergence to the steady state by augmenting the supply of lower-cost capital. Such countries are likely to prefer open capital markets, but in that case may face a delicate task in trading off domestic monetary policy goals against exchange stability. On the other hand, it is these structural features that renders it difficult for emerging market economies to apply floating dollar exchange rates to solve the trilemma and makes fixed exchange rates more vulnerable to crises when capital is internationally mobile. Most of these features have been discussed in earlier academic literature, and they continue to influence exchange rate policies in the non- industrial world today as quoted:

They include the tendency to avoid the domestic currency as a contractual unit of account and a lack of deep and resilient financial markets. Because these structural obstacles to fixing or floating stem from persistent institutional shortcomings, their recurrence in analyses of exchange rate policies is not hard to understand. These problems certainly help explain the limitations to date on emerging markets' realized gains from asset trade. (Obtsfeld, 2004)

Obtsfeld also touches upon the sudden stops in foreign lending, which force large exchange rate adjustments and, in the presence of liability dollarization, sharp deterioration in balance sheets. But overall, economists do not have a full understanding of the factors that have allowed industrial countries to escape from original sin and to avoid extensive denomination of domestic liabilities in foreign currencies. It seems more than likely, however, that histories of fiscal excess and inflation lower the perceived quality of domestic currency and make people reluctant to hold substantial creditor positions denominated in that currency's terms. So the problem stems from the weak government institutions that generate high and variable inflation. The phenomenon can be a circular one, because an inability to denominate debts in domestic currency leads to a harsher macroeconomic adjustment process, slower growth, and additional inflationary expropriations. Extensive foreign-currency liabilities make a floating exchange rate harder to live with, heightening the need for limiting exchange rate movements relative to that for interest rate independence under capital mobility. On the other hand, tighter limits on exchange rate fluctuations raise the likelihood of some sort of speculative attack on the currency as quoted:

As Eichengreen and Hausmann (1999) suggest, for some economies complete dollarization (of assets as well as liabilities, through abandonment of the national currency) may be the best solution of the trilemma. (Obtsfeld, 2003) 
If we look at the current situation in developing countries, we see that most emerging markets are transitioning to a limited flexibility or managed floating regime, although the extent of transition shows a large variability as shown in the following figure of Obtsfeld (2004).

Figure 9 Log Exchange Rate versus U.S. Dollar

[1] Brazil

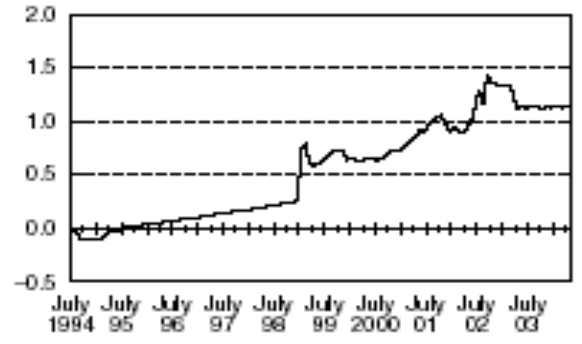

[3] Chile

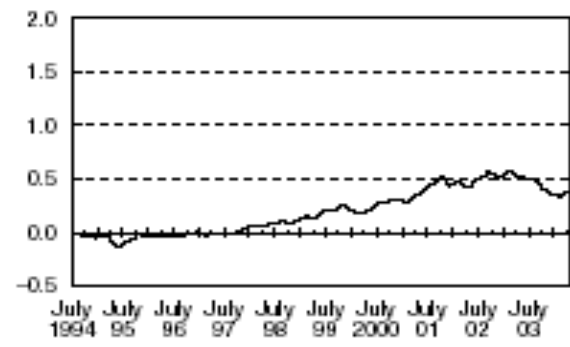

[5] Indonesia

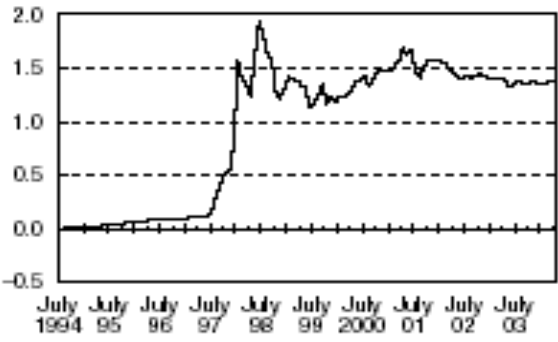

[7] Thailand

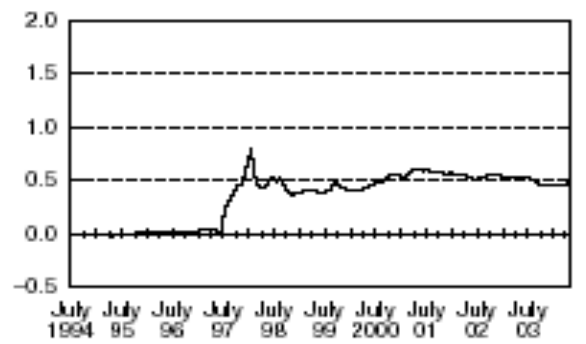

[2] Republic of Korea

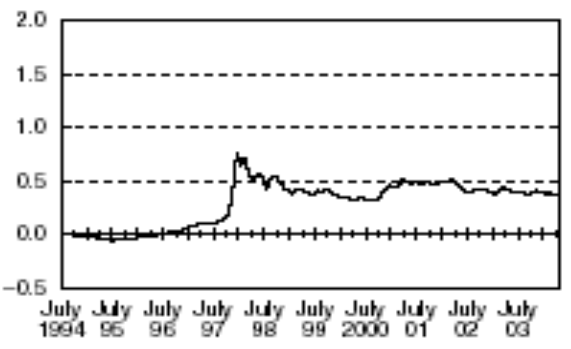

[4] Mexico

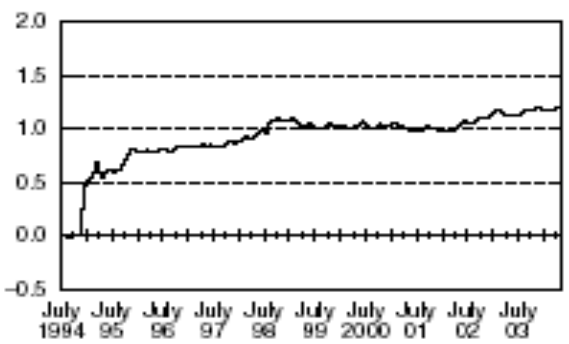

[6] Peru

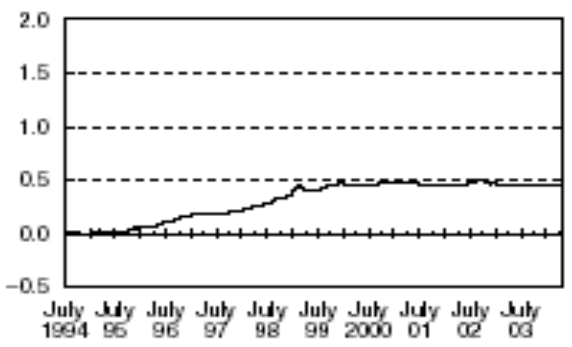

[8] Japan

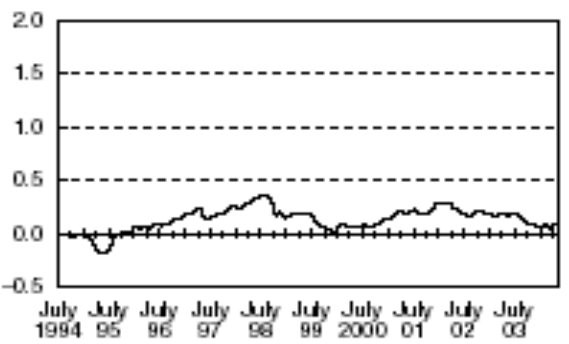

Source: Global Financial Data. Graphs show U.S. dollar's price in local currency. 
Overall, a few emerging markets (such as Chile) seem to be transitioning to fairly mature floating exchange rate arrangements. Others practice extensive smoothing, but may allow longer-term trends to accommodate gradual shifts in competitiveness. The financial vulnerabilities of these countries make large short term exchange rate movements perilous, but also make it unwise to set up a narrowly pegged rate as a target for speculation. Finally, even countries with a preference for stability will temporarily let the exchange rate loose under duress, as a kind of pressure-release valve. While the resulting volatility may have costs, it is preferable to drawing a line in the sand and daring speculators to cross it. A more stable exchange rate can be re-established once the turbulence has passed. These regime changes in exchange rate volatility, if present for industrial-country exchange rates, are much less pronounced.

In conclusion, Obtsfeld (2004) claims that developing countries have begun to perceive and realize economic gains from financial integration. However, they can only experience these gains in proportion to their institutional features which reduce the risks of liability generation, sudden stops, fear of floating, debt intolerance and currency mismatches that may turn to costly crises. While some emerging economies have been able to use floating successfully to relieve market pressures, others exhibit fear of floating, which is basically trading off the risks of currency crisis against those of excessive volatility. The insular countries, as expected, have on the whole performed worse than the emerging markets in terms of both average long-term growth and volatility. They have largely chosen to maintain closed capital accounts. Still this does not show the advantages of financial integration as quoted;

But it would be wrong to ascribe the superior performance of the emerging markets to financial openness. It is much more plausible that both relative economic success and the desire for integration into world capital markets stem from a superior institutional infrastructure of the economy. Improvement of that infrastructure is critical both in moving the poorest developing countries toward improved living standards and in ameliorating the difficulties emerging markets have encountered during financial globalization. (Obtsfeld, 2004)

\section{THE BIPOLAR VIEW OF EXCHANGE RATE REGIMES}

Policymakers involved in dealing with major international capital market related crises since 1994(Mexico, in 1994, Thailand, Indonesia and Korea in 1997, Russia and Brazil in 1998, and Argentina and Turkey in 2000) have warned strongly against the use of pegged rates for countries open to international capital flows. That warning has tended to take the form of advice that intermediate policy regimes between hard pegs and floating are not sustainable. This is the bipolar or two corner solution view, which is the subject of this lecture. In a recent paper of Stanley Fisher where he discusses the validity of this view, he argues that pegs are not sustainable unless they are very hard indeed; but that a wide variety of flexible rate arrangements are possible; and that it is to be expected that policy in most countries will not be indifferent to exchange rate movements as quoted:

To put the point graphically, if exchange rate arrangements lie along a line connecting free floating on the left with currency boards, dollarization or currency union on the right, the intent was not to remove everything but the corners, but rather to pronounce as unsustainable a segment of that line representing a variety of soft pegging exchange rate arrangements. (Fisher, 2001)

Fisher classifies countries into three main groupings which are hard pegs that consist of economies with currency boards or those with no separate currency, the intermediate group which consists of economies with conventional fixed pegs, crawling pegs, horizontal bands, and crawling bands and thirdly the floating group that consist of economies whose systems are described either as a managed float with no specified central rate, or as independently floating. When financial integration with the world markets is considered, the half of the two group of advanced and emerging countries use fixed exchange rate regimes whereas the other half applies floating systems. He stresses the main point that for developed and emerging market countries, adjustable peg exchange rate systems have not proved to be viable for the long term, and should not be expected to be viable. The names of the countries within these groups are as follows in Fisher (2001): 
Table 1. Developed Market Economies (as of December 31, 1999)

\begin{tabular}{|c|c|c|c|}
\hline & Euro Area & & Other \\
\hline & Exchange Arrangement & & Exchange Arrangement \\
\hline Austria & NS & Australia & IF \\
\hline Belgium & NS & Canada & IF \\
\hline Finland & NS & Denmark & $\mathrm{HB}$ \\
\hline France & NS & Hong Kong SAR & CBA \\
\hline Germany & NS & Japan & IF \\
\hline Ireland & NS & New Zealand & IF \\
\hline Italy & NS & Norway & MF \\
\hline Netherlands & NS & Singapore & MF \\
\hline Portugal & NS & Sweden & $\mathrm{IF}$ \\
\hline Spain & NS & Switzerland & IF \\
\hline & & United Kingdom & IF \\
\hline & & United States & IF \\
\hline
\end{tabular}

Source: IMF, Anmual Report 2000

Note: Economies listed in the MSCI Developed Markets index.

Key:

$\mathrm{NS}=$ Arrangements with no separate legal tender

$\mathrm{CBA}=$ Currency board

$\mathrm{FP}=$ Other conventional fixed pegs

$\mathrm{HB}=$ Pegged rate in horizontal band

$\mathrm{CP}=$ Crawling peg

$\mathrm{CB}=$ Rates within crawling bands

$\mathrm{MF}=$ Managed float with no pre-announced exchange rate path

$\mathrm{IF}=$ Independently floating 
Table 2. Emerging Market Economies (as of Decem ber 31, 1999)

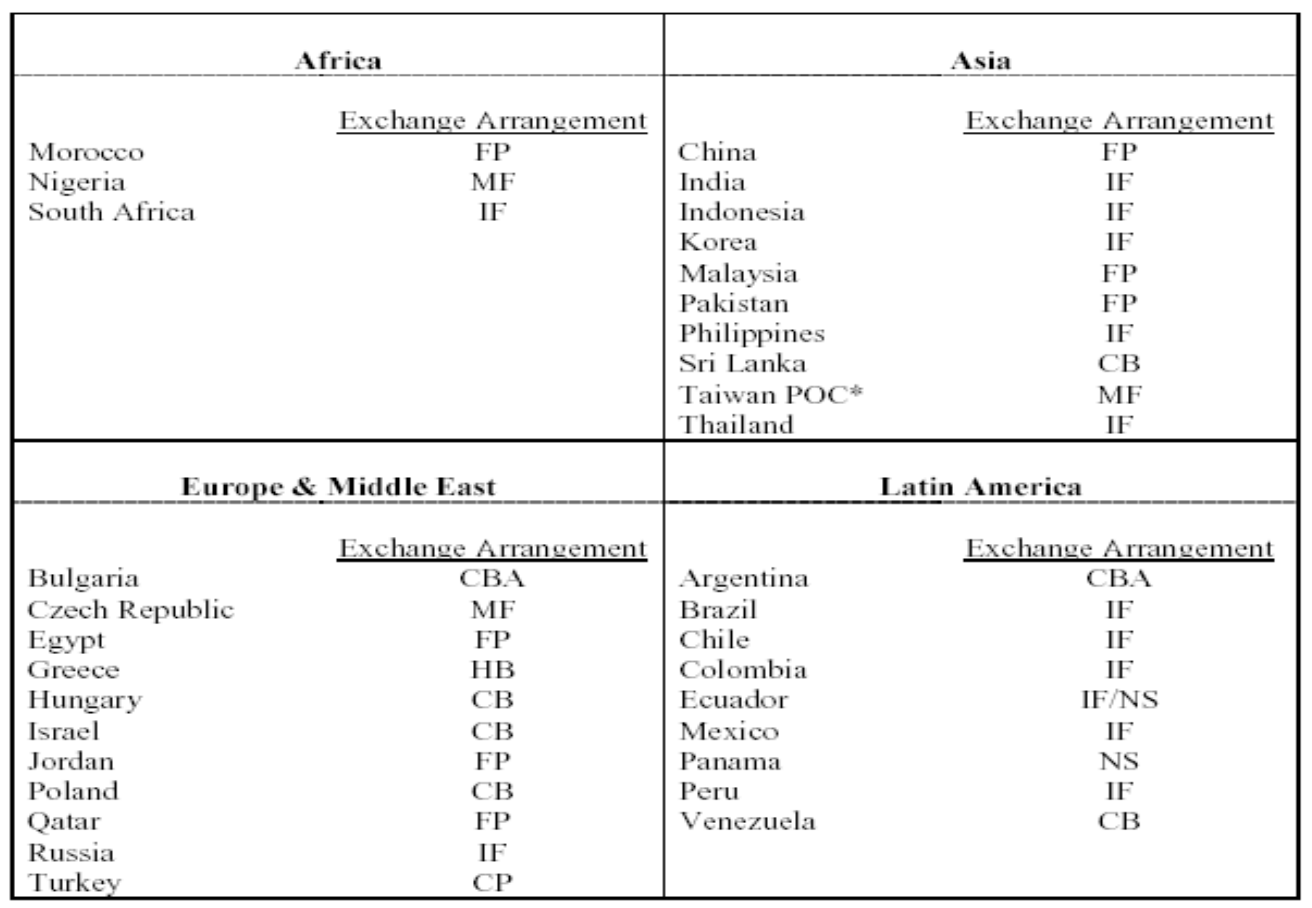

Source: IMF, Annual Report 2000

Note: Economies listed either and/or in the MSCI Emerging Markets and EMBI+ indices.

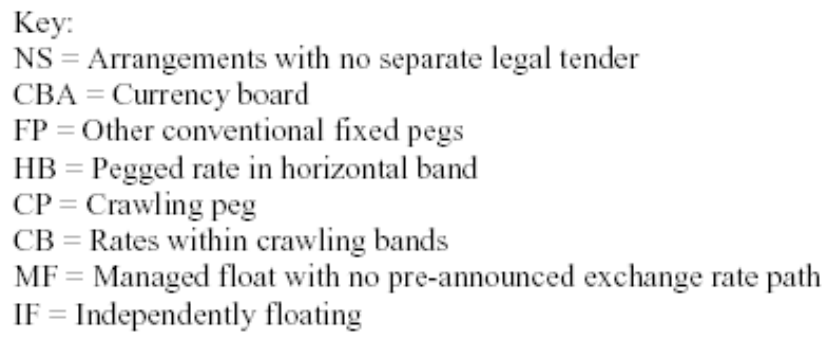

As we see in the tables above economies open to international capital flows have been and are in the process of moving away from adjustable peg exchange rate systems, some towards harder pegs, more towards systems with greater exchange rate flexibility. The possible reasons are listed as pressure of IMF and that soft peg systems have not proved viable over any lengthy period, especially for countries integrated or integrating into the international capital markets. Indeed in several countries, extensive damage has been caused by the collapses of pegged rate regimes which is partly explained by the impossible trinity of a fixed exchange rate, capital mobility, and a monetary policy dedicated to domestic goals.

On the other hand, many countries that claim to have floating exchange rates do not allow the exchange rate to float freely, but rather deploy interest rate and intervention policy to affect its behaviour. From this valid point they appear to draw two conclusions: first, that the claim that countries are moving away from adjustable peg exchange rate systems is incorrect; and second, that countries for good reasons hanker after fixed exchange rates, which they can best obtain through hard pegs. Recognizing the difficulty for an emerging market country of defending a narrow range of exchange rates, John Williamson (2000) proposes alternative regimes. He calls these BBC arrangements: basket, band, and crawl. He also recommends that countries if necessary allow the exchange rate to move temporarily outside the band, so that they do not provide speculators with one-way bets that lead to excessive reserve losses. In these circumstances, the band is serving as a weak nominal anchor for the exchange rate, 
but it is not at all clear why such a system is preferable to an inflation targeting framework. Possibly the band could be thought of as a supplement to an inflation targeting framework, but it would need to be demonstrated what if any benefits that brings.

Fisher (2003) concludes his study with a summary of facts. He claims that there is a continuing trend for most economies active in international capital markets that the share of both hard pegs and floating are gaining at the expense of soft pegs. The main reason for this change as claimed by Fisher, among countries with open capital accounts, is that soft pegs are crisis-prone and not viable over long periods which are primarily due to the logic of the impossible trinity. The move away from the centre is towards currency boards, dollarization, or currency unions on the hard peg side, and towards a variety of floating rate arrangements, including managed floating, on the other. As exchange rate flexibility increases, a country needs to determine the basis for its monetary policy. The record of inflation targeting has been a good one in this regard. The choice between a hard peg and floating depends in part on the characteristics of the economy, and in part on its inflationary history. Generally, the choice of a hard peg makes sense for countries with a long history of monetary instability, and/or for a country closely integrated in both its capital and current account transactions with another or a group of other economies. Fisher remarks that a wide variety of exchange rate systems is in use among non-emerging market developing economies, with the percentage of hard pegs among these economies being larger than it is among the emerging market countries and even among these economies, there was during the 1990s a movement away from soft pegs.

\section{CONCLUSION}

For an emerging market that is integrated with global financial markets, neither of the two exchange rate extremes seems to offer an attractive alternative. While the major industrialized countries have indicated a marked preference for either strong fixes or free floats, both of these solutions pose serious problems for countries with lessdeveloped financial markets, limited credibility, and rudimentary supervisory systems. On the other hand, traditional pegged exchange rates based on a fixed parity and narrow fluctuation bands have been shown to be inherently unstable and an open invitation to speculative attacks.

The most promising alternatives for most emerging markets would therefore seem to be the two new intermediate schemes. This is not to suggest that they are equally attractive, however. The MFP (Managed Floating Plus) exchange rate regime would have to be viewed as the more promising because it combines the desirable features of a flexible exchange rate regime (i.e., monetary policy independence and shock-absorbing properties) with a framework designed to address the major problems that have complicated the implementation of such a regime in emerging markets (i.e., lack of a nominal anchor and vulnerability to sudden exchange rate movements). In addition, this type of regime has already had some early success with countries such as Brazil, Chile, Mexico, and South Africa. Currency boards and dollarization are mostly useful as a last resort for countries suffering from original sin or too small to be able to have their own currency. Monetary union is a possibility for a few emerging markets, mainly the transition economies in Europe, but this set is rather small. Other options, such as the BBC (Baskets, Bands and Crawling pegs) exchange rate regime, might also be useful, but only as a transition regime, and should only be adopted with a clear exit strategy in mind.

In closing, it is worth emphasizing that no exchange rate system is best for all countries or for all times, and that no regime can act as a substitute for good policies and strong institutions. Indeed, the exchange rate regime should be viewed as part of a coherent monetary order, which is itself an integral part of a sound macroeconomic framework. 


\section{REFERENCES}

1. Alejandro, Diaz, Carlos F. (1975). Less Developed Countries and the Post-1971 International Financial System, Princeton Essays in International Finance, 108

2. Calvo Guillermo and Mishkin Frederic S. (2003). The Mirage of Exchange Rate Regimes for Emerging Market Countries, NBER Working Papers 9808

3. Calvo, Guillermo A. and Carmen M. Reinhart (2002). Fear of Floating Quarterly Journal of Economics, 117(2): 379-408.

4. Eichengreen, Barry (1998). Globalizing Capital: A History of the International Monetary System, Princeton: Princeton University Press.

5. Eichengreen, Barry and Ricardo Hausmann (1999). Exchange Rates and Financial Fragility, NBER Working Paper 7418

6. Fischer, Stanley (2001). Distinguished Lecture on Economics in Government - Exchange Rate Regimes: Is the Bipolar View Correct?, Journal of Economic Perspectives, 15(2): 3-24.

7. Fischer, Stanley (2003). Globalization and Its Challenges, American Economic Review 93: 1-30 (May)

8. Frankel, Jeffrey A. (1999). No Single Currency Regime is Right for All Countries or At All Times, Princeton University, International Finance Section, Essays in International Finance, No. 215 (August).

9. Masson, Paul (2000). Exchange Rate Regime Transitions, IMF Working Paper, WP/00/134 (July).

10. Mundell, R. (1961). A Theory of Optimum Currency Areas, American Economic Review, September, 657665.

11. Obstfeld, Maurice (1998). The Global Capital Market: Benefactor or Menace?, Economic Perspectives, Vol. 12, Number 4.

12. Obstfeld, Maurice (2004). Globalization, Macroeconomic Performance and The Exchange Rates of emerging Economies, NBER Working Paper, No 10849

13. Obstfeld, Maurice and Kenneth Rogoff (1995). The Mirage of Fixed Exchange Rates, Journal of Economic Perspectives, 9, 4 (Fall), 73-96.

14. Poole, William (1970). Optimal Choice of Monetary Policy Instruments in a Simple Stochastic Macro Model, The Quarterly Journal of Economics, MIT Press, vol. 84(2), pages 197-216, May

15. Williamson, John (2000). Exchange Rate Regimes for Emerging Markets: Reviving the Intermediate Option. Washington, DC: Institute for International Economics (September). 